\title{
Market Segmentation and Customer Focus Strategies and Their Contribution towards Effective Value Chain Management
}

\author{
Tarun Kanti Bose \\ Assistant Professor, Business Administration Discipline \\ Khulna University, Khulna-9208, Bangladesh \\ E-mail: tarun84ku@yahoo.com
}

Received: February 24, $2012 \quad$ Accepted: March 12, $2012 \quad$ Published: June 1, 2012
doi:10.5539/ijms.v4n3p113

\begin{abstract}
Today in this hyper-competitive business world, Each and every business entity is striving day and night to gain supremacy over others and few successfully obtained that destiny. Modern business is all about winning the stiff battle of competition with variety of business weapons and going ahead with making right changes in those weapons at the right time. Market segmentation and customer focus strategies are certainly two sharp weapons among those and can contribute profoundly for ensuring vast and fast growth. This article intended towards finding out the contribution of these two strategies for effective value chain. Explorative and qualitative research work has been done for achieving that goal. The findings suggests that market segmentation helps organizations to segment the whole market in an effective way and thus immensely assist in delivering diversified and customized product and services. On the other hand customer focus strategies also assist firm in great way to focus on specific customers and make am effective market and customer driven value chain.
\end{abstract}

Keywords: Value chain, Market segmentation, Customer focus strategies, Organizations

\section{Introduction}

Business conduction is more challenging than ever before and gaining competitive advantages in the market place is always the key attribute for sky high success. Every firm strives for that and few successfully obtained that destiny (Hewitt, 1994). Modern business is all about winning the stiff battle of competition with variety of business weapons and going ahead with making right changes in those weapons at the right time (Garbarino and Johnson, 1999). Every business firms are striving hard to find out the best possible weapons to ensure the competitive edge over the other operators and rivals. Finding out those weapons which are effective than ever before are never that easy and certainly require a lot of investment in research and development. Firms are investing a lot in those areas and certainly trying their best to ensure that they have right combination of business professionals and resources into their armory. Effective resources ensure effective operations and certainly can provide the firms that desired edge that they are looking for. It is always require having good look for the business professionals and business researchers to detect which methods and mechanisms are the best possible business weapons and the most effective utilization of the available resources for each and every firm. Effective value chain management is without any doubt a very proficient business weapons to have in the armory of every business organization. It ensures virtually everything for providing sound and better customer value and also assists to build long term sustainable relationship with the customers (Godsell and Harrison, 2002). As the concept of the perfect utilization of scarce resources take the center stage in the modern business which is increasingly becoming very difficult the immense importance of a good value chain gain even more significance. It is always the key to establish and certainly continue a sound and effective value chain for every firm and especially for the manufacturing firms' Modern marketing methods are always key ingredients for establishing a sound value chain. This article pays close attention to the effectiveness of the two most well established marketing strategies in the form of market segmentation and customer focus strategies for establishing a sound value chain for modern business firms.

\section{Research Question}

The main research question of this study is: 
- What is the contribution of market segmentation and customer focus strategies for establishing an effective value chain?

The entire research work has been done for the successful answering of the above mentioned research question.

\section{Methodology}

Research methods are always the key for each and every successful research work. It is certainly the base of every study. The research methods of this study have been established for the successful answering of the main research question. The main research question involved detecting and investigating the contribution of customer focus strategies and market segmentation for building and sustaining an effective value chain. In order to answer the question and finding out the contribution of those two strategies a qualitative research method has been utilized. A thorough review of the existing literature has been done and also the operation of the world's leading and successful business firms also has been monitored. Those firms in the practical world are actually practicing the customer focus and market segmentation strategy. Data has been collected form different books in the field of marketing, international business, management, business environment, economics and also from different well established journal articles. Those data has been processed and evaluated for figuring out the relevant information for this article and afterwards the derivation of the required information has been achieved. The entire research analysis has been done my making qualitative data analysis and also with bringing practical example of the firms. Those things combinedly evaluated the contribution of the customer focus and market segmentation strategies for establishing an effective value chain for each and every business organization.

\section{Conceptual Framework}

\subsection{The Concept of Value Chain}

The term "Value Chain" was first incorporated by Michael Porter in his book "Competitive Advantages" (Hines, 1993). The concept of value chain widely defined as the composition of some inter related value-adding activities that helps the organization in converting inputs into outputs in an efficient and effective manner and helping to create and sustain competitive advantages (Walters and Lancaster, 2000 and Hines and Rich, 1997). In normal cases a value chain consists of five primary activities in the form of: inbound distribution or logistic, manufacturing operations, outbound distribution, marketing and selling and after-sales services. The value chain also has four supporting activities as: purchasing or procurement, research and development, human resources management and corporate infrastructure (Porter, 1985 and Closs et al., 1998). The value chain in essence interprets the activities of the organization and relates it with competitive strengths and weaknesses in the market settings (Anderson and Mittal, 2000 and Ballou et al., 2000).

\subsection{Value Chain Analysis and Its Importance in Business Success}

An efficient and suitable value chain management is always the key for providing best products and services to the market place (Allnoch, 1997 and Walters and Rainbird, 2004). A typical value chain can be done in few steps. Those steps consists of firstly, analyzing the value chain of the company itself, then analyzing the value chain of the customers so that the organization can identify how the product will fit into the value chain of the customers, then analyzing the value chain of the competitors and finally identifying the potential value added for the customers through the company products or services (Corbett and Blackburn, 1999 and Gereffi et al., 2005).

From the above interpretation it is very obvious that value chain management is of huge importance for penultimate business success and growth. It helps organizations and management to set specific strategies and actions plan to create and sustain organization position and taking best benefit from the market (Agrawal and Pak, 2001 and Balsmeier and Voisin, 1996).

It not only evaluates the self-positioning and assessment of the corporations but also it reveals the expectations of the customers and also the current outlook and weapons of the competitors as well (Hines and Samuel, 2006 and Yuan-Jye, and Yu-Hua, 2007). There are different ways and process by which organization maintain efficient value chain management. Market Segmentation and different customer focus strategies are found to be the two of the most viable and effective solutions for establishing and maintaining highly performance oriented, robust and successful value chain management (Bolton, 1998 and Bowersox et al., 1999).

\section{Findings and Analysis}

\subsection{Market Segmentation and Its Importance for Effective Value Chain Management}

Market segmentation commonly referred as the process of segmenting market into different homogenous group (Elrod and Russell, 1982). Those groups tend to react differently to different marketing mix variables and therefore different strategies and value delivery options are require to establish successful comprehensive value 
chain management (Goller and Kalafatis, 2002). The immense importance of market segmentation resulted from the virtual reality of the differences in the consumers (Howaldt and Mitchell, 2007). Consumers of a product or service are no homogenous group and it is the fact that every consumer has individual needs, preferences, resources and unique behavior (Matzler and Hinterhuber, 1998). The problems faced by the producers are that it is totally impossible to provide different types of goods for different consumers. Therefore they group the market into homogenous clusters and segmentation is the most viable way to do it (McDonald and Dunbar, 2004). However, successful organization converts these difficulties as opportunities and use market segmentation as a perfect weapon to establish suitable value chain management and gaining the momentum and competitive edge (Howaldt and Mitchell, 2007).

Segmentation is without any doubt a good business tools but there is no single way to segment the market (Abratt, 1993). There are four basic ways to segment the market in the form of geographic, demographic, psychographic and behavioral segmentation. Geographic segmentation consists of variables like region, country size, city size, density, climate etc. Demographic segmentation consists of variable like age, gender, family size, family life cycle, income, occupation, education, religion, race nationality etc. Psychographic segmentation comprises of variables like social class, lifestyle, personality etc. Finally behavioral segmentation consists of variables like purchase occasion, benefits sought, user status, usage rate, loyalty status, readiness state, attitude toward product etc (Kotler and Armstrong, 2009, Hunt and Arnett, 2004 and Wedel and Wagner, 1999).

From the definition and structure of the market segmentation variables it is obvious that the process of segmentation helps the organization to specify the customer group and helps to establish specific product or service groups. By that way it assists a lot in building specific value chain activities for specific groups and therefore creates wonderful synchronization in the organization value chain maintenance for each and every target segments (Hunt and Arnett, 2004). The operation of global giant "Coca-Cola" portrays the significance of segmentation for operation efficiency. They offer different types of food items in addition to soft drinks in different global markets according to the customer preferences. For example they sell ready-to-drink coffee in Japan, curry Pringles crisps in England and funky soy sauce Pringles in Asia. This is the scenario of geographic segmentation which enables the company to establish suitable value chain in different types of markets according to customer preferences (Burnell, 1999 and Charles et al., 2000).

Market segmentation is always serves as the basis for customer orientation and differentiation (Haley, 1988). Therefore organizations can adopt effective value chain plan for target markets. "Tesco", the retail giant of the UK has three different types of stores: in big cities as Tesco Metro, in neighborhood as Tesco Express and One Stop in other small places. It helps the corporation to arrange their product items according to the choice of different inhabitants of those places and enables them to maintain strong and sound value chain management in all the places (Tesco, 2006).

Market segmentation is found to be the key for serving customer needs and wants in better ways (Hansotia and Wang 1997). The highly successful computer manufacturer "Dell" segments its market according to the customer groups like privates, small businesses, large businesses, public/state organizations. Then they make group products and that ensures high customer satisfactions as well. Because, there is no doubt in the fact that private users requires different computers than that of a large business organizations. This type of segmentation ensures that Dell's value chain is cost effective and directly linked with customer satisfaction (Oswald and Michael, 2009).

Segmentation is also helpful in making organization profitable through some changes in the value chain for different segments and charge more prices for better products or service category (Hauser, and Clausing, 1988). For instance, "Toyota" introduced "Lexus" the luxury car model and charge higher prices to get more profit from that as the customers of that's segments are ready to concede more for luxurious car (Kumar et al., 2006). The case is similar in airlines industry where world pioneer airlines like KLM (Royal Dutch Airlines) has business class customers and economy classes where they provide better services to the business class people and obtain more revenues from them (Reichheld, 2006).

Segmentation also assists in building individual approaches for target segments therefore helps the organization to keep the customer and also to capture new markets, because without specific focus customers may turned to market niche players who operates for specific segments (Jenkins and McDonald, 1996). The world giant "Procter and Gamble" makes "Crest Spinbrushes" with most likable characters of the children for kids segment and simultaneously it sells more serious models for adults featuring dentist's suggestions (Oswald and Michael, 2009). 
Market segmentation also enables organization to prioritize among their different market segments and ultimately helps the organization to put more emphasize on their most profitable market segments (Preece, 2002). It makes the organizational task easier because by this process companies can give more preferences on the highly profitable segments by giving the value delivery system more importance in overall the value chain management of the organization (Preece, 2002). Therefore, makes the value chain more efficient than ever before. "MTV" always focuses on their main target; the world teenagers. Therefore they make their programs based on love, crime, homelessness, lack of enough money and working parents. They try to eliminate the cultural differences and try to make the youths of Brazil, China, India and also of West's as their audiences (Kumar et al., 2006).

Segmentation is another great way to make the operation and value chain protected from risks (Rajib et al., 2002). Global giants like Adidas, Gillette, Toyota, Phillips, Unilever, Toyota, IBM, Apple, Sony, Disney, Wal-Mart, General Electric, segments their market not only for gaining supremacy and market share but also for diversification and risks spreading. Segmentation enables them to cover losses and inefficient value chain management of one places or category from an efficient one (Kumar et al., 2006). For example, during the most recent economic recession period the sales of Toyota go downward in Europe and in the US but they were able to cover it from Asia (Oswald and Michael, 2009).

\subsection{Customer Focused Strategies and Its Importance for Effective Value Chain Management}

While market segmentation process helps organization to segment the total market and specify operation and value chain management, customer-focused strategies provide the solutions to satisfy the customers of those segments up to the fullest extent (Cao and Gruca, 2005 and Center of Quality Management Journal, 1993). Customer focused strategy has been defined as a plan that put all the focus on the needs and expectations of a particular customer segments and organizations which traditionally follow this strategy tend to emphasize customer needs above all the phenomenon including the organization itself (Alba et al., 1997 and Treacy and Wiersema, 1993). From the term customer focused strategy only one conclusion can be drawn. That is customer is above everything and organization should also do virtually everything to satisfy them. Customer focused strategies also helps the organization in practicing efficient value chain management in several ways (Charles et al., 2002 and Claes and Roland, 1997).

Customer focused strategies enhances communications capability of the organizations with its customers and the corporation become well informed about what customers wants from them (Akao, 1990 and Anderson et al., 1994). Therefore the organization can create such value chain management which is according to the customer preference and has the chance to fulfill customer expectations (Verma et al., 1999 and Waller et al., 1999).

In the designing studio of Global Automobile giant "Toyota", customers come and design car according to their choice. From that Toyota get comprehensive ideas about the forthcoming consumer's choice s about car design and make their value chain according to fulfill customer demand (Lemon et al., 2002).

There is no better advertisement than fully satisfied customers and on the other dissatisfied customers are the worse (Gummesson, 1996). Satisfaction resulted long term relationship with the customer and it is always the best for the company if the retention and loyalty rate is high (Taylor, 2005). Customer focus strategy helps companies to create such value chain which enables them to create and maintain customer loyalty (Gupta and Lehman, 2003). The world leading petroleum corporation "BP" has more than 1 million interactions with the customers everyday and for doing so they have 100000 staffs in 100 countries. Those interactions assist the company to understand what customers want and they build their value chain accordingly (Lemon et al., 2002). The world giant in this field, the "Royal Dutch Shell" also practices intense customer focus strategies and that is why also they are so successful (Reichheld, 2006).

Customer focus strategies make the most efficient value chain as it ensures cost effectiveness and less wastage (Inger et al., 1995). It reduced the inventory costs and also organization require to take less research and development activities because customers focus strategies ensure free flow of information within customers and the company (James, 1994 and Zeithaml, 1993). The company understands everything and can operate accordingly. The leading retailer of the UK the "Richer Sounds" shops always listen every visitor of the store through a specific card. In that card they write that thanks for your support to make us number one, now tell us what we should do to maintain this. From the suggestions of the visitors they establish their value chain activities by correcting the mistakes and problem areas (Naudé and Cheng, 2003).

It helps the organization to build core competencies as customers focus strategies gives clear cut idea and organization is open to create and manage effective and appropriate value chain strategies. It helps to practice modern efficient value chain and management activities like TQM (Total Quality Management), BPR (Business 
Process Reengineering), CRM (Customer Relationship Management) etc (Berry, 1983 and Blattberg et al., 2001). The leading golf equipment manufacturer "Ping" maintain strong database which contains special assembly instructions for designing golf clubs for each customer and easy replacements as well. When they receive order they can process it in very fast way in their value chain system. This gives the company an edge in a very saturated market. They are practicing this CRM and also TQM in their value chain strategies for nearly two years successfully (Knowles, 2002).

Through the practices of customer focused strategies organizations value chain management also get maximum chances of highly innovative and most importantly innovative from the customer's point of view (Gupta et al., 2002 and Zokaeiand and Simons, 2006). This process ensures innovativeness more appropriate. The main goal is always to satisfy customers and in that process customers are also taking part to give it more viability (O'Brien and Jones, 1995).

One of the leading banks of the world the "ING" bank of the Netherlands has developed "Self-serve banking", which is highly innovative not because their managements or technical experts have invented that practice rather it is innovated by the customers. Now it is innovative and simultaneously effective mechanism in their overall value chain as they were customer focused and that resulted penultimate business success. As a result their profit soared by $200 \%$ last year (Kotler, 2009).

The organization which adopts customer focused strategies in their value chain management believes the philosophy that "Customers knows the best" (Gustafsson et al., 2005). Therefore their value chain is demand driven rather than supply driven. It ensures highly effective and appropriate use of the organization value chain resources for most suitable management practices. It also ensures high success rate and low case of market failures of products and services (Ross, 1998). The employees of Swedish Ferry "Stena" have the authority to spend up to 1500 Euros for solving customers problems at any time without management permission. That makes their customer the real feel of satisfaction every time and makes the organization's value chain an efficient one (Lewis, 2005.a).

\section{Conclusion}

Modern business organizations always have to deal with immense uncertainties and stiff competitions (Hakansson and Snehota, 1995). Successful dealing with uncertainties and competition requires up to date and innovative business weapons (Barratt, 2004). Investment in the right places, at the right time and on the right track is always the key to keep every threat behind and stepping towards desired destiny (Jones and Riley, 1985). Organizational financial as well as human capital need to be goal directed and invested in appropriate sectors (Lewis, 2005b). The analysis of different global pioneer organizations reveals that their success stories always rooted in the areas of identifying suitable opportunities and capitalize those by utilizing the value chain management perfectly. Global dominators like Nike, Ford, Procter and Gamble, 3M, Hewlett Packard, Google, Sony, Siemens, Airbus, Boeing, Starbucks, General Motors, Mercedes, Coca-Cola and others, never let the opportunities go begging (Sherer, 2005). They have utilized those up to maximum extent and one thing is common in all those organizations value chain management. That common thing is all of them have segmented markets and they follow specific customer focus strategies for all those segments (Lewis, 2005b). The success journey of the global leading corporations articulates the huge importance of market segmentation and customer focus strategies for highly successful value chain management (Anderson et al., 2004). Market segmentation helps to segment the market and provide the opportunities for differentiation, focus, specific needs fulfillment whereas customer focus strategies enables the organization to understand customers and provide them what actually they want (Steenkam and Hofstede, 2002). Successful management of value chain is definitely the key for long term management and organizational achievement and market segmentation and customer focus strategies are of huge significance for efficient value chain management without any slimmest of doubt (Lewis, 2005b).

\section{References}

Abratt, R. (1993). Market segmentation practices of industrial marketers. Industrial Marketing Management, 22, 79-84. http://dx.doi.org/10.1016/0019-8501(93)90033-4

Agrawal, M. K., \& Pak, M. H. (2001). Getting smart about supply chain management. McKinsey Quarterly, 2, 22-7.

Akao, Y. (1990). Quality Function Deployment: Integrating Customer Requirements into Production Design. Productivity Press, Cambridge, MA. 
Alba, J., Lynch, J., Weitz, B., \& Janiszewski C. et al. (1997). Interactive home shopping: Consumer, retailer, and manufacturer incentives to participate in electronic marketplaces. Journal of Marketing, 61(3), 38-53. http://dx.doi.org/10.2307/1251788

Allnoch, A. (1997). Efficient supply chain practices mean big savings to leading manufacturers. IIE Solutions, 29(7), 8-9.

Anderson, E. W., \& Mittal, V. (2000). Strengthening the satisfaction profit chain. Journal of Service Research, 3(2), 107-120. http://dx.doi.org/10.1177/109467050032001

Anderson, E. W., Fornell, C., \& Lehmann, D. R. (1994). Customer satisfaction, market share, and profitability: Findings from Swedem. Journal of Marketing, 58, 53-66. http://dx.doi.org/10.2307/1252310

Anderson, E. W., Fornell, C., \& Mazvacheryl, S. K. (2004). Customer satisfaction and shareholder value. Journal of Marketing, 68(4), 172-185. http://dx.doi.org/10.1509/jmkg.68.4.172.42723

Ballou, R. H., Gilbert, S. M., \& Mukherjee, A. (2000). New managerial challenges from supply chain $\begin{array}{llllll}\text { opportunities. } & \text { Industrial } & \text { Marketing } & \text { Management, } & 29 & \text { (1), }\end{array}$ http://dx.doi.org/10.1016/S0019-8501(99)00107-8

Balsmeier, P. W., \& Voisin, W. J. (1996). Supply chain management: a time-based strategy. Industrial Management, 38(5), 24-8.

Barratt, M. (2004). Unveiling enablers and inhibitors of collaborative planning. International Journal of Logistics Management, 15(1), 73-91. http://dx.doi.org/10.1108/09574090410700248

Berry, L. L. (1983). Relationship marketing. In Berry, L. L., Shostack, G. L., \& Upah, G. D. (Eds), Emerging Perspectives on Services Marketing. American Marketing Association. Chicago, IL, 497-506.

Blattberg, R. C., Getz, G., \& Thomas, J. S. (2001). Customer Equity: Building and Managing Relationships as Valued Assets. Boston, Massachusetts: Harvard Business School Press.

Bolton, R. N. (1998). A dynamic model of the duration of the customer's relationship with a continuous service provider: The role of satisfaction. Marketing Science, 17(1), 45-65. http://dx.doi.org/10.1287/mksc.17.1.45

Bowersox, D .J., Closs, D. J., \& Stank, T. P. (1999). $21^{\text {st }}$ Century Logistics: Making Supply Chain Integration a Reality. Council of Logistics Management, Oak Brook, IL.

Burnell, J. (1999). Change management: the key to supply chain success. Automatic I.D. News, 15, 40-51.

Cao, Y., \& Gruca, T. S. (2005). Reducing adverse selection through customer relationship management. Journal of Marketing, 69(4), 219-229. http://dx.doi.org/10.1509/jmkg.2005.69.4.219

Center of Quality Management Journal. (1993). Special issue on Kano's methods for understanding customer-defined quality. Center of Quality Management Journal, 2(4), 12-21.

Charles, H., Fine, R., Vardan, R., Pethick \& J. El-Hout. (2000). Rapid-Repsonse Capability in Value-Chain Design. MITSloan Management Review, 43(2), 14-23.

Claes, F, \& Roland T. R. (1997). Customer Satisfaction, Productivity, and Profitability: Differences between Goods and Services. Marketing Science, 16(2), 129-45. http://dx.doi.org/10.1287/mksc.16.2.129

Closs, D. J., Roath, A. S., Goldsby, T. J., Eckert, J. A., \& Swartz, S. M. (1998). An empirical comparison of anticipatory and response-base supply chain strategies. International Journal of Logistics Management, 9(2), 21-34. http://dx.doi.org/10.1108/09574099810805816

Corbett, C. J., \& Blackburn, J. D. (1999). Partnerships to improve supply chains. MIT Sloan Management Review, 40(4), 71-83.

Elrod, T., \& Russell, S. W. (1982). An Empirical Evaluation of Aggregation Approaches for Developing Market Segments. Journal of Marketing, 46, 65-74. http://dx.doi.org/10.2307/1251363

Garbarino, E., \& Johnson, M.S. (1999). The different roles of satisfaction, trust, and commitment in customer relationships. Journal of Marketing, 63(2), 70-87. http://dx.doi.org/10.2307/1251946

Gereffi, J., Humphrey, G., \& Sturgeon, T. (2005). The Governance of Global Value Chains. Review of International Political Economy, 12(1), 78-104. http://dx.doi.org/10.1080/09692290500049805

Godsell, J., \& Harrison, A. (2002). Customer responsive supply chains: an exploratory view of performance measurement. Paper presented at PMA Conference, Boston, MA. 
Goller, S. A., \& Kalafatis, S. P. (2002). A new research agenda for business segmentation. European Journal of Marketing, 36(1-2), 252-71. http://dx.doi.org/10.1108/03090560210412782

Gummesson, E. (1996). Relationship marketing and the imaginary organisation: a synthesis. European Journal Marketing, 30(2), 31-44. http://dx.doi.org/10.1108/03090569610106635

Gupta, S., \& Lehman, R. (2003). Customers as assets. Journal of Intercative Marketing, 17(1), 9-24. http://dx.doi.org/10.1002/dir.10045

Gupta, S., D., Lehman, R., \& Stuart, J. A. (2002). Valuing customers. Journal of Marketing Research, XLI, $7-18$.

Gustafsson, A., Johnson, M. D., \& Roos, I. (2005). The effects of customer satisfaction, relationship commitment dimensions, and triggers on customer retention. Journal of Marketing, 69, 210-218. http://dx.doi.org/10.1509/jmkg.2005.69.4.210

Hakansson, H., \& Snehota, I. (1995). Developing Business Relationships, Routledge, London.

Haley, R. I. (1988). Benefit segmentation: a decision-oriented research tool. Journal of Marketing, 32, 30-35. http://dx.doi.org/10.2307/1249759

Hansotia, B. J., \& Wang, P. (1997). Analytical challenges in customer acquisition. Journal of Direct Marketing, 11(2), 7-19. http://dx.doi.org/10.1002/(SICI)1522-7138(199721)11:2<7::AID-DIR3>3.0.CO;2-V

Hauser, J. R., \& Clausing, D. (1988). The house of quality. Harvard Business Review, 66(3), 63-73.

Hewitt, F. (1994). Supply chain redesign. International Journal of Logistics Management, 5(2), 1-9. http://dx.doi.org/10.1108/09574099410805162

Hines, P. (1993). Integrated materials management: the value chain redefined. International Journal of Logistics Management, 4(2), 13-22. http://dx.doi.org/10.1108/09574099310804920

Hines, P., \& Rich, N. (1997). The seven value stream mapping tools. International Journal of Operations \& Production Management, 17(1), 17-29. http://dx.doi.org/10.1108/01443579710157989

Hines, P., \& Samuel, D. (2006). The development of supply chain relationships: a multi lens approach. Working paper, Cardiff Business School, Cardiff.

Howaldt, K., \& Mitchell, A. (2007). Can segmentation ever deliver the goods? Market Leader, 36 (Spring).

Hunt, S. D., \& Arnett, D. B. (2004). Market segmentation strategy, competitive advantage and public policy: grounding segmentation strategy in resource-advantage theory. Australasian Marketing Journal, 12(1), 7-25. http://dx.doi.org/10.1016/S1441-3582(04)70083-X

Inger, R., Braithwaite, A., \& Christopher, M. (1995). Creating a manufacturing environment that is in harmony with the market: the 'how' of supply chain management. Production Planning and Control, 6(3), 246-58. http://dx.doi.org/10.1080/09537289508930277

James, H. D. (1994). Linking Customer Satisfaction to Service Operations and Outcomes. In Roland T. Rust \& Richard L. Oliver (Eds.), Service Quality: New Directions in Theory and Practice. Newbury Park, CA: Sage Publications, Inc., 173-200.

Jenkins, M., \& McDonald, M. (1996). Market segmentation: organizational archetypes and research agendas. European Journal of Marketing, 31(1), 17-32. http://dx.doi.org/10.1108/03090569710157016

Jones, T., \& Riley, D.W. (1985). Using inventory for competitive advantage through supply chain management. International Journal of Physical Distribution \& Materials Management, 15(5), 16-26.

Knowles, G. (2002). QFD: customer driven design of products and services. In Antony, J., Kulp, S. C., Lee, H. L., \& Ofek, E. (2004), Manufacturing benefits from information integration with retail customers. Management Science, 50(4), 431-44.

Kotler, P., \& Armstrong, G. (2009). Principle of Marketing. European Edition, London.

Kumar, V., Leman N. K., \& Parasuraman, A. (2006). Managing customers for value: An overview and research agenda. Journal of Service Research, 9(2), 87-94. http://dx.doi.org/10.1177/1094670506293558

Lemon, K. N., White, T. B., \& Winer, R. S. (2002). Dynamic customer relationship management: Incorporating future considerations into the service retention decision. Journal of Marketing, 66, 1-14. http://dx.doi.org/10.1509/jmkg.66.1.1.18447 
Lewis, M. (2005a). A dynamic programming approach to customer relationship pricing. Management Science, 51(6), 986-994. http://dx.doi.org/10.1287/mnsc.1050.0373

Lewis, M. (2005b). Incorporating strategic consumer behavior into customer valuation. Journal of Marketing, 69 , 230-238. http://dx.doi.org/10.1509/jmkg.2005.69.4.230

Matzler, K., \& Hinterhuber, H. H. (1998). How to make product development projects more successful by integrating Kano's model of customer satisfaction into quality function deployment. Technovation, 18(1), 25-38. http://dx.doi.org/10.1016/S0166-4972(97)00072-2

McDonald, M., \& Dunbar, I. (2004). Market Segmentation: How to Do it, How to Profit from it. Oxford: Elsevier.

Naudé, P., \& Cheng, L. (2003). Choosing between potential friends: market segmentation in a small company. Paper presented at the 19th IMP Conference, Lugano, Switzerland. [Online] Available: www.impgroup.org/conferences.php (January 4, 2011).

O’Brien, L., \& C. Jones (1995). Do rewards really create loyalty? Harvard Business Review, 73(3), 75-82.

Oswald, A. M., Ram Kesavan, \& Michael, B. (2009). Customer value-chain involvement for co-creating customer delight. The Journal of Consumer Marketing, 21(7), 486-496.

Porter, M. (1985). Competitive Advantage, Creating and Sustaining Superior Performance. The Free Press, New York.

Preece, D. (2002). Understanding Managing and Implementing Quality. Routledge, London, 57-80.

Rajib, P., Tiwari, D., \& Srivastava, G. (2002). Design and development of an integrated supply chain management system in an internet environment. Journal of Services Marketing, 3(13), 12-19.

Reichheld, Fred. (2006). The Microeconomics of Customer Relationships. MITSloan Management Review, 47(2), SMR197. Cambridge: Massachusetts Institute of Technology.

Ross, D. F. (1998). Competing through supply chain management. Creating Market-winning Strategies Through Supply Chain Partnership. Kluwar Academic Publishers, Boston, MA.

Sherer, S. A. (2005). From supply-chain management to value network advocacy: implications for e-supply chains. Supply Chain Management, 10, 77 - 89. http://dx.doi.org/10.1108/13598540510589151

Steenkamp, E. M., \& Hofstede, F. (2002). International Market Segmentation: Issues and Perspectives. International Journal of Research in Marketing, 19(3), 185-213. $\mathrm{http}: / / \mathrm{dx}$. doi.org/10.1016/S0167-8116(02)00076-9

Taylor, D. H. (2005). Value chain analysis: an approach to supply chain improvement agri-food chains. International Journal of Physical Distribution \& Logistics Management, 35(10), 744-61. http://dx.doi.org/10.1108/09600030510634599

Tesco. (2006). Our core purpose, Tesco. [Online] Available: www.tescocorporate.com (Janaury 2, 2011).

Treacy, M., \& Wiersema, F. (1993). Customer intimacy and other value disciplines. Harvard Business Review, January-February.

Verma, R., Thompson, G., \& Louviere, J. (1999). Configuring Service Operations in Accordance with Customer Needs and Preferences. Journal of Services Research, 1(3), 262-74. http://dx.doi.org/10.1177/109467059913007

Waller, M. A., Dabholkar, P. A., \& Gentry, J. J. (2000). Postponement, product customization, and marketoriented supply chain management. Journal of Business Logistics, 21 (2), 133-61.

Walters, D., \& Lancaster, G. (2000). Implementing value strategy through the value chain. Management Decision, 38(3), 160-178. http://dx.doi.org/10.1108/EUM0000000005344

Walters, D., \& Rainbird, M. (2004). The demand chain as an integral component of the value chain. The Journal of Consumer Marketing, 21, 465. http://dx.doi.org/10.1108/07363760410568680

Wedel, M., \& Wagner, A. K. (1999). Market Segmentation: Conceptual and Methodological Foundations. Boston: Kluwer Academic Publishers.

Yuan-Jye, T., \& Yu-Hua, L. (2007). The Grey Relational Evaluation of the Manufacturing Value Chain. Journal of American Academy of Business, 7(1), 67-71. Cambridge.

Zeithaml, A. (1993). A Dynamic Model of Service Quality: From Expectations to Behavioral Intentions. Journal of Marketing Research, 30, 7-27. http://dx.doi.org/10.2307/3172510 
Zokaei, K., \& Simons, D. W. (2006). Value chain analysis in improvement of customer focus: a case study of $\mathrm{UK}$ red meat industry. International Journal of Logistics Management, 17(2), 22-35. http://dx.doi.org/10.1108/09574090610689934 